Мельник Л. М., к.е.н., доцент, Яковчук Ольга, студентка (Національний університет водного господарства та природокористування, м. Рівне)

\title{
МЕХАНІЗМ ФІНАНСУВАННЯ ВИЩОї ОСВІТИ В УКРАЇНІ
}

В статті розглянуто теоретико-методологічні та практичні аспекти організації системи фінансування вищої освіти. Досліджено джерела та механізм фінансового забезпечення закладів вищої освіти. Виявлено головні проблеми фінансового механізму. Проаналізовано сучасний стан фінансування вишів. Надано пропозиції щодо підвищення якості фінансування закладів вищої освіти. Ключові слова : фінансування вищої освіти, заклад вищої освіти, джерела фінансування, видатки на вищу освіту, фінансовий механізм.

Вища освіта, а саме практика їі фінансування, завжди мала та продовжує зберігати істотне соціально-економічне і політичне значення для розвитку будь-якої країни. В сучасних умовах місце та значення вищої освіти в системі пріоритетів, що вибудовуються кожною країною, відображають рівень соціально-економічного розвитку нації. Тільки маючи відповідну сучасним стандартам вищу освіту, та чи інша країна може претендувати на гідне місце та визнання в світі.

Дослідженням проблем стану та динаміки фінансового забезпечення вищої освіти займалося чимало вітчизняних науковців. 3окрема, у працях В. Базилевича, Г. Беккера, Т. Боголіб, З. Варналія, А. Віфлєємського, О. Грішнової, Т. Єфименко, В. Жаміна, Е. Жильцова, С. Струмиліна, І. Чугунова, А. Чухно, Т. Шульца, С. Юрія, Л. Якобсона та ін. піднято питання ролі освіти в розвитку суспільства, напрацьовано ефективні механізми регулювання системи освіти.

Разом із тим, неоднозначність економічної природи освіти (як суспільного і приватного блага) зумовлює складність побудови механізму її фінансування, який може бути диверсифікованим за формами, методами і ресурсами. Для кожної країни залишається надзвичайно актуальною проблемою пошук власного механізму, оптимального і ефективного з точки зору інтересів суспільства.

Метою даної статті $\epsilon$ дослідження та аналіз організації фінансування вищих навчальних закладів України, а також обґрунтування пропозицій щодо його покращення.

Становлення в Україні ринкових відносин, інтеграція країни у 
світову економічну систему обумовлює необхідність змін у професіональній структурі зайнятого населення, насамперед спеціалістів вищої та середньої кваліфікації.

Узагальнюючи думки вчених, які досліджували в своїх працях систему фінансування вищої освіти, можемо стверджувати, що механізм фінансового забезпечення вищої освіти - це сукупність форм, методів, інструментів та важелів, пов'язаних з фінансовим забезпеченням та фінансовим регулюванням сфери вищої освіти $[1 ; 2 ; 3]$.

Отже, фінансовий механізм ми розглядаємо як сукупність двох функціональних підсистем:

фінансове забезпечення - система джерел та форм фінансування розвитку економічної і соціальної сфер суспільства. Стосовно функції фінансового забезпечення слід зазначити, що вона змінюється в сторону диверсифікації джерел фінансування освіти, зменшення державної частки у загальній сумі фінансових ресурсів вищої освіти;

фінансове регулювання - метод фінансового впливу, пов'язаний з регулюванням економічних процесів.

Згідно ст. 71 Закону України «Про вищу освіту», фінансування державних вищих навчальних закладів здійснюється за рахунок коштів державного бюджету на умовах державного замовлення на оплату послуг з підготовки фахівців та за рахунок інших джерел, не заборонених законодавством, з дотриманням принципів цільового та ефективного використання коштів, публічності та прозорості у прийнятті рішень [4].

В Україні фінансування вищої освіти здійснюється за наступними формами [5]:

- фінансування бюджетне - форма централізованого виділення з державного бюджету фінансових ресурсів шляхом безповоротного, безоплатного надання коштів, інвестицій на розвиток економіки, соціально культурні заходи, оборону та інші господарські потреби;

- фінансування кошторисне - фінансування відповідно до затвердженого кошторису;

- фінансування кошторисно-бюджетне - надання державою коштів на утримання установ, що перебувають на бюджетному фінансуванні, здійснюване за фінансовими планами-кошторисами витрат;

- фінансування пряме - спосіб фінансування, за якого кошти спрямовуються безпосередньо від власників заощаджень до позичальників без участі фінансових посередників;

- фінансування непряме - сукупність фінансових ринкових ка- 
налів, по яким грошові кошти спрямовуються від власників заощаджень до позичальників через фінансових посередників;

- фінансування цільове - виділення фінансових ресурсів для досягнення певної мети, вирішення конкретної соціальноекономічної проблеми, створення конкретного об'єкта.

Форми фінансування освіти в межах державних та недержавних джерел більш детально наведено в табл. 1.

Таблиця 1

Джерела фінансування вищої освіти [5]

\begin{tabular}{|c|c|}
\hline & \\
\hline $\begin{array}{l}\text { - пряме фінансування (з од- } \\
\text { ного або декількох рівнів дер- } \\
\text { жавного управління) на основі } \\
\text { кошторисів або нормативів; } \\
\text { - додаткові асигнування за } \\
\text { окремими категоріальними про- } \\
\text { грамами, заходами тощо (на- } \\
\text { приклад, програма підтримки } \\
\text { кращих студентів); } \\
\text { - виділення матеріальних ре- } \\
\text { сурсів, надання пільг; } \\
\text { - дотації або субвенції для } \\
\text { вирівнювання диспропорцій між } \\
\text { регіонами; } \\
\text { - за конкурсом; } \\
\text { - фінансування специфічних } \\
\text { програм (кредитування навчан- } \\
\text { ня, ваучерна освіта, харчування } \\
\text { малозабезпечених дітей); } \\
\text { - за формулою, яка враховує } \\
\text { певні кількісні та якісні показ- } \\
\text { ники діяльності навчального за- } \\
\text { кладу }\end{array}$ & $\begin{array}{l}\text { - кошти, одержані на навчан- } \\
\text { ня, підготовку та перепідготовку } \\
\text { кадрів відповідно до укладених } \\
\text { договорів; } \\
\text { - кошти, одержані за науко- } \\
\text { во-дослідні та інші роботи, ви- } \\
\text { конані закладом освіти на замо- } \\
\text { влення підприємств, установ та } \\
\text { громадян; } \\
\text { - дотації з місцевих бюджетів; } \\
\text { - доходи від реалізації проду- } \\
\text { кції навчально-виробничих май- } \\
\text { стерень, підприємств, від надан- } \\
\text { ня в оренду приміщень, споруд, } \\
\text { обладнання; } \\
\text { - плата за надання додатко- } \\
\text { вих освітніх послуг; } \\
\text { - кредити і позики банків, ди- } \\
\text { віденди від цінних паперів та } \\
\text { доходи від розміщення на депо- } \\
\text { зитних вкладах тимчасово віль- } \\
\text { них коштів; } \\
\text { - добровільні грошові внески, } \\
\text { матеріальні цінності, одержані } \\
\text { від підприємств, установ, органі- } \\
\text { зацій, громадян. }\end{array}$ \\
\hline
\end{tabular}

Законодавчо закріплено, що держава має забезпечити загальні асигнування на освіту в розмірі не менше 7\% ВВП за рахунок коштів державного, місцевих бюджетів та інших джерел фінансування, не заборонених законодавством. Якщо порівнювати видатки державного бюджету на освіту відносно ВВП в Україні, які в середньому складають 6-7\%, із відповідним показником у зарубіжних країнах, то 
складається враження про досить високий рівень фінансування галузі освіти (табл. 2).

Таблиця 2

Видатки зведеного бюджету на освіту за 2000-2017 роки [6]

\begin{tabular}{|c|c|c|c|c|}
\hline \multirow{2}{*}{ Показники } & \multirow{2}{*}{$\begin{array}{c}\text { Сума, млн } \\
\text { грн. }\end{array}$} & \multicolumn{2}{|c|}{ Видатки у \% до } & \multirow{2}{*}{$\begin{array}{c}\text { Видатки на } \\
\text { окремі під- } \\
\text { галузі у \% } \\
\text { до видатків } \\
\text { на галузь }\end{array}$} \\
\hline & & $\begin{array}{c}\text { загальних } \\
\text { видатків }\end{array}$ & ВВП & \\
\hline \multicolumn{5}{|c|}{2000 рік } \\
\hline Видатки бюджету : & 48148,6 & 100,0 & 100,0 & $\mathrm{X}$ \\
\hline $\begin{array}{c}\text { з них } \\
\text { на освіту - всього: }\end{array}$ & 7085,5 & 14,7 & 4,2 & 100,0 \\
\hline ут. ч. на вищу & 2285,5 & 4,7 & 1,3 & 32,3 \\
\hline \multicolumn{5}{|c|}{2010 рік } \\
\hline Видатки бюджету: & 377842,8 & 100,0 & 100,0 & $x$ \\
\hline $\begin{array}{c}\text { з них } \\
\text { на освіту - всього: }\end{array}$ & 79826,0 & 21,1 & 7,4 & 100,0 \\
\hline ут. ч. на вищу & 24998,4 & 6,6 & 2,3 & 31,3 \\
\hline \multicolumn{5}{|c|}{2017 рік } \\
\hline Видатки бюджету: & 1056759,9 & 100,0 & 100,0 & $x$ \\
\hline $\begin{array}{c}3 \text { них } \\
\text { на освіту - всього: }\end{array}$ & 177755,7 & 16,8 & 6,0 & 100,0 \\
\hline ут. ч. на вищу & 38681,1 & 3,7 & 1,3 & 21,8 \\
\hline
\end{tabular}

Аналізуючи рівень фінансування освіти в Україні за останні роки, можна зробити висновки, що з 2000 по 2010 рік спостерігалася тенденція зростання бюджетних витрат на освіту в цілому і, на вищу освіту зокрема (з 4,2\% до 7,4\% та з 1,3\% до 2,3\% ВВП відповідно).

Однак, з 2011 по 2017 роки видатки зведеного бюджету на освіту знизились до 6\% від ВВП, що, насамперед, пов'язано із значним зниженням самого ВВП. Питома вага видатків на вищу освіту у загальній сумі видатків зведеного бюджету зменшилась 3 6,6\% у 2010 році до 3,7\% у 2017 році. Щодо даних видатків у фінансуванні галузі освіти в цілому, то вони в середньому становлять близько $25 \%$, що оцінюється негативно, оскільки на вищу освіту повинно спрямовуватися не менше $40 \%$ від загальної суми видатків на освіту.

Хоча за останні роки в абсолютному виразі держава дещо збільшила обсяги видатків із державного бюджету на вищу освіту, про- 
те воно $є$ незначним, результатом чого є скорочення доступу громадян до отримання вищої освіти, передусім, на навчання за рахунок державного бюджету.

32010 р. припинено державне фінансування комунальних витрат вищих навчальних закладів, які, так само як і закупівля обладнання і книг, оновлення гуртожитків, фінансуються з доходів від платного навчання. Призупинено бюджетне фінансування пільгових кредитів на будівництво житла для науково-педагогічного персоналу. Вкрай обмежене зарубіжне стажування у провідних освітніх центрах світу за державний кошт. Оплата праці викладачів вищих навчальних закладів залишається низькою.

Протягом останніх років триває тенденція зниження кількості студентів вишів, що пояснюється як демографічними проблемами (стрімке зниження кількості молоді, що народилася у першій половині 90-х років), так і недостатністю фінансових ресурсів внаслідок загострення фінансово-економічної кризи (табл. 3).

Таблиця 3

Чисельність студентів 3 ВО за джерелами фінансування їх навчання [7]

\begin{tabular}{|l|c|c|c|c|}
\hline \multirow{2}{*}{\multicolumn{1}{|c|}{ Показники }} & \multicolumn{3}{|c|}{ BH3 III-IV рівнів акредитації } \\
\cline { 2 - 5 } & $\begin{array}{c}2014 / \\
2015\end{array}$ & $\begin{array}{c}2015 / \\
2016\end{array}$ & $\begin{array}{c}2016 / \\
2017\end{array}$ & $\begin{array}{c}2017 / \\
2018\end{array}$ \\
\hline \multicolumn{1}{|c|}{ Всього студентів, тис. осіб } & 1438,0 & 1375,2 & 1369,4 & 1329,96 \\
\hline $\begin{array}{l}\text { 3 них навчається } \\
\text { за кошти: }\end{array}$ & 46,1 & 47,2 & 47,7 & 45,8 \\
- державного бюджету, \% & & & & \\
\hline - місцевих бюджетів, \% & 0,8 & 1,1 & 0,9 & 1,0 \\
\hline - юридичних осіб, \% & 0,7 & 0,7 & 0,7 & 0,5 \\
\hline - фізичних осіб, \% & 52,4 & 51,0 & 50,7 & 52,7 \\
\hline
\end{tabular}

Очевидно, що за досліджуваний період кількість студентів зменшилась на 7,5\%. І за прогнозом вчених зниження чисельності студентів ЗВО триватиме щонайменше до 2022 року, що підтверджується даними про кількість учнів середніх шкіл.

Більшість студентів навчаються за свої власні кошти, так економіка забезпечується кваліфікованою робочою силою, підготовленою без бюджетного фінансування. Бюджетне фінансування проводиться переважно через кошти державного бюджету, натомість частка участі місцевих бюджетів надзвичайно низька.

Таким чином, сучасний стан вищої освіти характеризується нестачею бюджетних коштів, що виділяються для забезпечення функціонування цієї сфери діяльності. Це, в свою чергу, негативно впли- 
ває на розвиток матеріальної бази, науково-дослідного потенціалу, рівень і якість підготовки фахівців.

Згідно зі Законом України «Про вищу освіту», фінансування державних вищих навчальних закладів здійснюється за рахунок коштів державного бюджету. Така структура фінансування відповідає загальноєвропейським тенденціям, але, разом з тим, потрібно враховувати рівень інфляції, індекс споживчих цін, абсолютний та відносний показники обсягів фінансування [7].

Незважаючи на університетську автономію, українські державні університети залишаються повністю залежними від держави, тому не мають можливості прийняти на себе відповідальність за якість своєї діяльності. Хоч фінансова автономія надає більш широкі можливості отримання та розподілу фінансування, а також можливостей позичати кошти і залишати у розпорядженні ЗВО невикористані бюджетні кошти, виші України отримують державне фінансування у формі однорічного постатейного бюджету. Майбутні законодавчі реформи в освіті повинні надати навчальним закладам можливість залучати додаткові надходження на фінансових ринках. Таким чином, і держава, і влада, і університети можуть визначити інноваційні шляхи диверсифікації та збільшення фінансових потоків 3В0 [8].

Для фінансової автономії ЗВО важливе значення має благодійне фінансування, яке ставатиме ще важливішим у майбутньому. Під ним розуміють широкий спектр типів фінансування: фінанси надані приватними особами; надходження, отримані від благодійних організацій (фондів), зазвичай спрямованих на досягнення визначених цілей i, нарешті, надходження, отримані від благодійних фондів, що фінансують наукові дослідження [9].

Аналіз зарубіжного досвіду дає змогу виділити основні інструменти фінансування закладів вищої освіти, які, своєю чергою, можуть бути використані в Україні [1]: пряме бюджетне фінансування на покриття витрат; пряме бюджетне фінансування за програмноцільовим методом (орієнтоване на досягнення результату); бюджетне фінансування з використанням державних зобов'язань (освітніх ваучерів); освітнє кредитування; освітні заощадження; грантове кредитування; отримання плати за навчання від споживачів освітніх послуг; корпоративне фінансування (коштом корпорацій або майбутніх роботодавців).

Для розвитку фінансового забезпечення вищої освіти основними напрямками повинні бути [9]:

- організаційні: забезпечення повного інноваційноорганізаційного циклу для прикладних наукових розробок; активіза- 
ція маркетингової діяльності вузів; своєчасне оновлення активів вузів;

- фінансові: розподіл бюджетних коштів не на основі нормативів, а за результатами діяльності, що стимулює відповідальність керівників освітніх установ за досягнення встановлених стандартів якості навчання; економне витрачання фінансових ресурсів; оптимізація організаційної структури 3В0; застосування лізингових і кредитних інструментів у фінансовому забезпеченні; зміна в політиці ціноутворення на освітні послуги; формування запасів фінансових ресурсів; фінансова підтримка кращих студентів контрактної форми навчання; застосування системи матеріального заохочення працівників за успішні проекти із залучення додаткових фінансових ресурсів.

Для формування ефективного фінансового забезпечення освіти навчальним закладам необхідно здійснювати постійний моніторинг своєї діяльності, який дозволить виявити кількісні оцінки соціальноекономічних наслідків здійснених державою заходів в освітній сфері та визначити перспективний розвиток фінансування освіти вишів України.

3 метою стабілізації освітньої галузі необхідно:

- вжити рішучих заходів щодо збільшення та диверсифікації фінансування вищої освіти в Україні, а отже, удосконалити науковометодичне забезпечення освітнього процесу та створити умови для проведення фундаментальних та прикладних досліджень у навчальних закладах, які, в свою чергу, виступатимуть додатковим джерелом фінансування вищої освіти в Україні;

- довести фінансування освіти до 7\% від ВВП;

- посилити контроль уряду за виконанням у повному обсязі норм Конституції України та вимог законів України «Про освіту» та «Про вищу освіту», інших нормативно-правових актів, що стосуються сфери вищої освіти, щоб не допустити безконтрольної комерціалізації вищої освіти.

Висновки. Отже, формування та забезпечення реалізації реформ у вищій школі, забезпечення України висококваліфікованими кадрами, затребуваними на ринку праці, збільшення попиту на освітні послуги та приведення освітніх стандартів до стандартів розвинених країн, вимагає розроблення ефективного механізму фінансування освіти в Україні. Реалізація запропонованих заходів має сприяти розширенню самостійності, економічної автономії вищих навчальних закладів. Важливим у вдосконаленні фінансового механізму вищої освіти $є$ активізація ролі позабюджетних джерел, в тому числі коштів за надані освітні послуги, від виконання договірних робіт господарського характеру, спонсорських коштів тощо. Негайний розг- 
ляд проблем фінансування освіти та розроблення заходів щодо їх вирішення дасть змогу Україні найближчим часом гармонізуватись із освітнім європейським простором, підвищити конкурентоспроможність української вищої освіти та стати повноправним учасником Болонського процесу.

1. Боголіб Т. М. Фінансування вищої освіти України: проблеми і перспективи їх вирішення. American Scientific Journal. 2017. № 1 (9). С. 70-78. 2. Варналій 3. С. Фінансування державних вищих навчальних закладів України. Київ : Знання України, 2017. 231 с. 3. Вахович І. М. Фінансове забезпечення вищої освіти: методологія та механізм реалізації в умовах формування соціально орієнтованої ринкової економіки. Луцьк : РВВ ЛНТУ, 2010. 286 с. 4. Про вищу освіту : Закон України від 01.07.2014 № 1556 Л/II. URL: http://zakon5.rada.gov.ua/laws/show/1556-18. (дата звернення: 15.01.2019). 5. Касич А. О., Циган В. А. Особливості фінансування вищої освіти в Україні та інших країнах світу. Ефективна економіка. 2013. № 12. URL: http://www.economy.nayka.com.ua/?op=1\&z=2587. 6. Освіта в Україні: Базові індикатори. Інформаційно-статистичний бюлетень результатів діяльності галузі освіти у 2017/2018 https://base.kristti.com.ua/?p=7325 (дата звернення: 15.01.2019). 7. Основні показники діяльності вищих навчальних закладів України на початок 2016/17 навчального року : статистичний бюллетень. URL: http://www.ukrstat. gov.ua/metaopus/2016/1-1_03_00_03_2016.htm. (дата звернення: 15.01.2019). 8. Красільник О. В. Проблеми та перспективи фінансування вищих навчальних закладів України. Вісник Київського національного ун-ту імені Тараса Шевченка. Економіка. 2015. № 2 (167). С. 110117. 9. Економічні аспекти проблем розвитку вищої освіти в Україні: монографія / за ред. чл.-кор. НАПНУ І. М. Грищенка. Хмельницький : ХНУ, 2010. 478 c.

\section{REFERENCES:}

1. Boholib T. M. Finansuvannia vyshchoi osvity Ukrainy: problemy i perspektyvy yikh vyrishennia. American Scientific Journal. 2017. № 1 (9). S. 70-78. 2. Varnalii Z. S. Finansuvannia derzhavnykh vyshchykh navchalnykh zakladiv Ukrainy. Kyiv : Znannia Ukrainy, 2017. 231 s. 3. Vakhovych I. M. Finansove zabezpechennia vyshchoi osvity: metodolohiia ta mekhanizm realizatsii $v$ umovakh formuvannia sotsialno oriientovanoi rynkovoi ekonomiky. Lutsk : RVV LNTU, 2010. 286 s. 4. Pro vyshchu osvitu : Zakon Ukrainy vid 01.07.2014 № 1556 L/II. URL: http://zakon5.rada.gov.ua/laws/show/1556-18. (data zvernennia: 15.01.2019). 5. Kasych A. 0., Tsyhan V. A. Osoblyvosti finansuvannia vyshchoi osvity $v$ Ukraini ta inshykh krainakh svitu. Efektyvna ekonomika. 2013. № $12 . \quad$ URL: http://www.economy.nayka.com.ua/?op=1\&z=2587. (data zvernennia: 
15.01.2019). 6. Osvita v Ukraini : Bazovi indykatory. Informatsiino-statystychnyi biuleten rezultativ diialnosti haluzi osvity u 2017/2018 n.r. 2018 r. 209 s. : URL: https://base.kristti.com.ua/?p=7325 (data zvernennia: 15.01.2019). 7. Osnovni pokaznyky diialnosti vyshchykh navchalnykh zakladiv Ukrainy na pochatok 2016/17 navchalnoho roku : statystychnyi biulleten. URL: http://www.ukrstat. gov.ua/metaopus/2016/1-1_03_00_03_2016.htm. (data zvernennia: 15.01.2019). 8. Krasilnyk 0. V. Problemy ta perspektyvy finansuvannia vyshchykh navchalnykh zakladiv Ukrainy. Visnyk Kyivskoho natsionalnoho un-tu imeni Tarasa Shevchenka. Ekonomika. 2015. № 2 (167). S. 110-117. 9. Ekonomichni aspekty problem rozvytku vyshchoi osvity v Ukraini: monohrafiia / za red. chl.-kor. NAPNU I. M. Hryshchenka. Khmelnytskyi : KhNU, 2010. 478 s.

Рецензент: д.е.н., професор Савіна Н. Б. (НУВГП)

Melnyk L. M., Candidate of Economics (Ph.D.), Associate Professor, Yakovchuk Olha, Senior Student (National University of Water and Environmental Engineering, Rivne)

\section{MECHANISM OF FINANCING OF HIGHER EDUCATION IN UKRAINE}

The article deals with theoretical-methodological and practical aspects of the organization of the system of financing higher education. The sources and mechanism of financial support of higher education institutions, which contains two functional subsystems: financial security and financial regulation, are investigated. The forms of financing of higher education, in particular budget, estimated, budgetary-estimated, direct, indirect and targeted financing are considered. The main problems of the financial mechanism, which are the lack of budget funds, the low level of use of additional sources of financing, and the low level of autonomy of higher education institutions are revealed. The current state of financing of educational institutions is analyzed. Measures to improve the quality of funding for higher education institutions are identified: diversification of funding sources, improvement of scientific and methodological provision of educational process and creation of conditions for conducting fundamental and applied research in educational institutions; strengthening the control over the full implementation of legislative acts concerning the sphere of higher education. Organizational directions for improving the financial provision of higher education include the provision of a full innovation and organizational cycle for applied research; activization of marketing activities of universities; 
timely updating of assets of high schools. The financial areas include: the distribution of budget funds is not based on norms, but on the results of activities; economical spending of financial resources; application of leasing and credit instruments in financial security; a change in pricing policy for educational services; formation of financial resources; financial support of the best students of contractual form of education; application of the system of material incentives for employees for successful projects to attract additional financial resources.

Keywords: financing of higher education, institution of higher education, sources of financing, expenditures on higher education, financial mechanism.

Мельник Л. М., к.э.н., доцент, Яковчук Ольга, студентка (Национальный университет водного хозяйства и природопользования, г. Ровно)

\section{МЕХАНИЗМ ФИНАНСИРОВАНИЯ ВЫСШЕГО ОБРАЗОВАНИЯ В УКРАИНЕ}

В статье рассмотрены теоретико-методологические и практические аспекты организации системы финансирования высшего образования. Исследованы источники и механизм финансового обеспечения учреждений высшего образования. Выявлены главные проблемы финансового механизма. Проанализировано современное состояние финансирования вузов. Даны предложения по повышению качества финансирования высших учебных заведений.

Ключевые слова: финансирование высшего образования, учреждение высшего образования, источники финансирования, расходы на высшее образование, финансовый механизм. 